\title{
SPECTACLES AND EMBROIDERED SPECTACLE CASES FROM CHINA IN THE NÁPRSTEK MUSEUM
}

\author{
Helena Heroldová ${ }^{1}$
}

\begin{abstract}
Spectacles from China appear in many museum collections, and they are popular collectibles in private collections. The collection of ten spectacles and their cases in the Náprstek Museum in Prague shows its technological and material development from the pince-nez type in the second half of the $19^{\text {th }}$ century to early $20^{\text {th }}$ century tortoiseshell and plastic spectacles. As signs of learning, these different types of spectacles and their cases show their social context and meaning in Chinese society during the transition period from the traditional to the modern era.
\end{abstract}

KEY WORDS: Chinese Culture - late Qing - dress accessories - spectacles - Náprstek Museum - museum collections

\section{Introduction}

Spectacles represent both a medical aid as well as a fashionable accessory. Moreover, spectacles have had a centuries-old history associated with prominent discoveries in medicine and physics, with developments in the fields of arts and craftsmanship of various materials, and with intercultural exchange as the knowledge of principles of lenses and their manufacture were transmitted between medieval Europe, the Muslim world, India and China. Today, nineteenth-century spectacles from China are found in museum collections as a representation of every-day life culture, ${ }^{2}$ as well as in private

1 Contact: Helena Heroldová, National museum - Náprstek Museum of Asian, African and American Cultures; e-mail: helena_heroldova@nm.cz. This work was financially supported by Ministry of Culture of the Czech Republic (DKRVO 2018/32, DKRVO 2019-2023/19.I.a, National Museum, 00023272).

2 See for example the British Museum (https://www.britishmuseum.org/research/collection_online/ search.aspx?searchText=spectacles) and Quai Branly in Paris (http://www.quaibranly.fr/en/ explore-collections/base/Work/action/show/notice/866743-le-mandarin-aux-lunettes/). Although spectacles are found in museum and private collections, their social context is rarely discussed in the works dealing with Chinese material culture. The meaning of spectacles since the late $19^{\text {th }}$ until the mid-20 $0^{\text {th }}$ century is discussed Dikötter, 2006: 214-215, and the construction and materials of spectacles cases is found in Garrett, 2001: 113-115, with pictures). As discussed further in the article, the early studies about spectacles focused mainly on the textual evidence of their origin.

This work is licensed under the Creative Commons Attribution-Noncommercial-No Devivs 3.0 License 
collections of historical eyeglasses (Rasmussen, 1915, Rosenthal, 1996). This study deals with the collection of spectacles and spectacle cases from China kept in the Náprstek Museum. Although the collection represents a relatively small set, it contains items associated with significant collectors and travellers whose collections are now found in the Museum. One pair of spectacles was already published in a work dealing with their original collector (Heroldová, 2011) however; this article is the first one to describe the whole collection. Spectacles that cross the line between the every-day life necessities and dress accessories represent the initial case-study in the detailed examination of late Qing clothing accessories in their social context. As compared to previous research dealing with the male and female Han and Manchu clothes in the late $19^{\text {th }}$ century (Heroldová, 2017), this detailed research will focus on jewellery, dress accessories and items of personal every-day use.

\section{The Origin of Spectacles in China}

Some scholars assumed that Muslim travellers introduced eyeglasses to China at the end of the $14^{\text {th }}$ or the early $15^{\text {th }}$ century both via the inland route through Central Asia and the maritime route across the Indian Ocean and Indonesia (Mazor and Hershkovitz, 2013: 305). ${ }^{3}$ However, scholars also suggested an earlier date of introduction during the Yuan dynasty (1271-1368) that coincides with its spread in Europe (Chiu, 1936: 191, 193). The question concerning when spectacles appeared in China and their possible Chinese origin became the topic of early studies. Two early twentieth-century notable scholars in Chinese culture - the anthropologist Berthold Laufer (1874-1934) from the Fields Museum in Chicago and the head of Harvard-Yenching Library in Harvard University Alfred Kaiming Chiu (1898-1977) - devoted their time to the study of the history of spectacles in China. They based their research on written sources from the Yuan dynasty that contained earlier Song dynasty (960-1279) notes (Chiu, 1936: 186, Laufer, 1907). ${ }^{4}$ Their research influenced later studies by Joseph Needham (1900-1995), who discussed optics in the enormous encyclopaedic project Science and Civilisation in China (1946-2016) that he had initiated and co-authored. According to his study of written sources, magnifying lenses and dark glasses for eye protection were known during the Song dynasty, and other optical devices such as reading glasses, mirrors, burning glasses, telescopes and microscopes were known and used during the Ming (1368-1644) dynasty (Needham, 2004: 99-122). ${ }^{5}$

The Chinese terms for "spectacles" reveal how the knowledge of them was transmitted in the vast area between the Near and Middle East, India and China, and

3 Glasses appeared in the Muslim world probably in the $14^{\text {th }}$ century and in India in the late $15^{\text {th }}$ and early $16^{\text {th }}$ century according to written sources (Agarwal, 1971: 128). In the Muslim world they were probably available through contacts with Italian traders (Mazor and Hershkovitz, 2013: 291). The reading glasses were produced in the $13^{\text {th }}$ century in Northern Italy (Needham, 2004: 120, Mazor and Hershkovitz, 2013: 296). However, convex lenses made of precious stones were probably known since antiquity.

4 The texts from the Song and Yuan dynasties have a complex textual history including later additions and rewritings. The later post-Yuan editions thus contained information that was added later. The textual history of written sources was not fully known to the early authors of works about Chinese spectacles.

5 Joseph Needham proposed the idea that spectacles originated in China like other inventions that were later transmitted to the West (Needham, 2014: 118). Needham's interpretation of the dissemination of scientific knowledge is today reflected in critical views (Finlay, 2000: 267). 
was the same as with many other technological and scientific inventions. One of the early terms for spectacles, aidai 叆 叇 with the meaning of "obscure, dark, cloudy" (Needham, 2004: 120, translation from Chinese: "loving to reach through a cloudy screen") was probably a transliteration of the Arabic term 'al - 'uwaynāt (العوينا ت, "little eyes") and Persian 'aynak (عينك). (عين) Another early Chinese term aina 矮納 is similar to the Arabic term 'cayn - eye (عين) (Mazor and Hershkovitz, 2013: 305, Needham, 2004: 120). Since the $16^{\text {th }}$ century (Chiu, 1936: 190), the term yanjing 眼 鏡 ("eye mirror") appeared and has been used in the Chinese language until today. The terms reflect the appropriation and development of scientific vocabulary in Chinese. The early terms were based upon a phonological appropriation, while the later term represents an example of a descriptive neologism (Lackner, 2004: 541).

Various optical devices including reading glasses, telescopes and magnifying lenses were used in the $17^{\text {th }}$ century among the members of the Chinese literati class (Chen, 2018: 94). In this cultural context they served not only as personal aids but also as means of exploring the surrounding nature. The woodblock print booklet entitled Jingshi (鏡 史, “History of Lenses") by Sun Yunqiu 孫雲球 (1629-1662) described optical devices, and the written text was accompanied with illustrations that expressed the meaning of the devices. Simultaneously, the booklet served as a product advertisement. Moreover, the customisation of the products to individual needs was emphasised. For example, when eyeglasses were needed, one's vision was measured, and the lenses were manufactured according to individual needs (Chen, 2018: 93).

\section{The Cultural Meaning of Spectacles}

In the booklet History of Lenses, spectacles were described as an aid for elderly people who wanted to improve their vision. When the eyes of old people deteriorated, no medicine helped, and spectacles offered a method for the improvement of one's eyes (Chen, 2018: 88-89). However, glasses were also recommended for young men who spent years of studies in order to attend the Imperial Examination and become civil officials in the traditional bureaucratic system of Imperial China (Chen, 2018: 93). Spectacles became a sign of learning, education and social position among the educated élite (Garrett, 2001: 115, Dikötter, 2006: 214). Spectacles also became a symbol of modernity, especially in the cosmopolitan cities during the early decades of the $20^{\text {th }}$ century when "society girls and professional beauties" wore them as a fashionable ornament (Dikötter, 2006: 216).

Berthold Laufer in his study from 1907 provided some remarks about the social behaviour of Chinese who wore spectacles. Spectacles should be taken off when a person meets someone for the first time and introduces oneself, since it is considered rude to stare at a new acquaintance through the glasses. The officials were not allowed to wear spectacles during Court audiences and in front of senior officials (Laufer, 1907: 384-385).

Popular books depicting life during the last years of the Qing Dynasty often mention the story of the last Emperor Puyu's spectacles in order to demonstrate the alleged backwardness of the Imperial household staff. Reginald Fleming Johnston (1874-1938), who served as the tutor to Aisin-Gioro Puyi (1906-1967) from 1919 to 1924 depicted in his memoires how he discovered that the Emperor could not see quite well and arranged

\footnotetext{
6 The author expresses her gratitude to Matěj Stahl, matej_stahl@nm.cz for transcribing the Arabic script.
} 
a visit of an ophthalmologist in the Forbidden City. The alarmed household staff at first did not want to admit that the Emperor could suffer from an eye defect. Eventually, Puyi was examined by the specialist. The story appeared also in Puyi's autobiography, and later came to general awareness as one of the stories depicting humiliation of the former Emperor of a one-time mighty Empire in the movie The Last Emperor (Bertolucci, 1987). However, Puyi enjoyed wearing eye glasses and was devoted to them. (AisinGioro, 1965: 124, Johnston, 2011: 272-273)

\section{Construction and Materials}

The frames of spectacles in China in the $19^{\text {th }}$ century and early $20^{\text {th }}$ century were made from various materials. Metal wires made of steel and iron were considered cheap (Dikötter, 2006: 215). Horn and tortoiseshell from the hawksbill sea turtle (Eretmochelys imbricata) were common materials. Later, plastic ${ }^{7}$ was also used, and the products made from artificial materials were called "chemical glasses" (huaxue yanjing 化學眼鏡， Dikötter, 2006: 215). ${ }^{8}$

In the $19^{\text {th }}$ century spectacles were tied with a silk ribbon around the head (Bock, 1903: 4-5, Laufer, 1907: 384). They were also secured around the head with double folding arms with round ends. Besides this traditional type, modern sidepieces around the ears were used (Dikötter, 2006: 216).

Lenses were made of quartz and glass ${ }^{9}$ (Garrett, 2001: 115). Dark glasses were used either for sun protection or as a fashion accessory (Dikötter, 2006: 215).

Spectacles were stored in cases made from various materials. Some solid cases were made of wood with a varnish finish, glued paper and textiles, and shagreen ${ }^{10}$ - rawhide from sharks and ray fish whose rough surface was popular for its aesthetic qualities. Until today those types of spectacle cases are appreciated by collectors.

\section{The Origin of the Náprstek Museum Collection}

The collection contains ten pieces of eyeglasses in eight spectacle cases. The earliest acquisition (No. 4) comes from the Collection of the Museum of Czech Kingdom (Museum Království českého), as the present-day National Museum was entitled between 1854 - 1919, and can be dated to the second half of the $19^{\text {th }}$ century. Unlike this acquisition, the exact dates and provenience are known in two pairs of spectacles (Nos. 5, 6) brought from China by Václav Stejskal (1851-1934), a navy commissioner. Václav Stejskal entered the Austro-Hungarian Navy in 1871, and after service on several warships was appointed (by his own request) to the military corvette Aurora on her journey to Asia in 1886. After his return in 1889, he was promoted, and two years later

7 Museum curators dealing with late $19^{\text {th }}$ and early $20^{\text {th }}$ century items from China can meet with objects made of plastic that imitate natural materials. Parkensine, known also as the artificial ivory appeared in the mid-19 $9^{\text {th }}$ century. Galalith, manufactured in 1893, also resembled ivory. Bakelite was patented in 1909. However, with only a visual comparison and without a destructive method of analysis it is often difficult to distinguish different types of plastics from one another as well as from natural materials.

8 The term huaxue 化 學 appeared in the mid-19 $9^{\text {th }}$ century as a newly coined term for Western style chemistry, see Lackner, 2004: 403, Wright, 2000: 416.

9 Manufacture of glass was known to Chinese since the first millennium BC (Needham, 2004: 101), but glass was used only marginally.

${ }^{10}$ For example, spectacles and the case, Musée Quai Branly, Paris, France, Inv. No. 71.1969.125.258.1-3. 
he left the Navy and became a high official in Vienna, the capital of the AustroHungarian Empire. He spent the last decades of his life with his wife in Bohemia, near Prague in a villa where he exhibited his collection. Stejskal accumulated his large collection during his travel through Southeast Asia, China, and Japan. After his return, he gave away a large part as gifts. During the first decades of the $20^{\text {th }}$ century, a part of his collection was stolen and was lost during the First World War period. Eventually, approximately one thousand items from Asia were given to the Náprstek Museum after his death. Roughly one hundred items were acquired in China. They represented mainly souvenir goods available in large international ports; however, the collection also contains every-day objects used by the Chinese (Heroldová, 2011).

One pair of spectacles (No. 1) belonged to the collection acquired by the traveller and photographer Enrique Stanko Vráz (1860-1932). E. S. Vráz visited China for the second time in 1901. Although he stayed there only for three months from January to April, his visit is important due to its purpose and results. Vráz travelled to China intentionally in order to witness and capture in photographs the violent and muchfeared Boxer Rebellion, the rural class uprising against the presence of foreigners in China. When Vráz arrived to Beijing, the rebellion was already in its final stage. However, Vráz used his stay to make a series of photographs depicting the lives of ordinary people of Beijing as well as Manchu aristocracy. He also collected various objects, but the lack of financial support and his further travel plans apparently prevented him from acquiring a collection of large and financially valuable items (Heroldová and Todorovová, 2018).

Three pairs of spectacles (Nos. 7, 8, 9) belonged to the collection of Joe Hloucha (1881-1957). Hloucha was known during the 1920s and 1930s as an art collector and a successful writer of sentimental novels set in Japan. He admired traditional Japanese culture, although his large collection contained also objects from China and other regions of Asia, and European mediaeval and folk art (Kraemerová and Šejbl, 2007).

Unfortunately, the origin of two pairs of metal-wired spectacles in almost identical cases (Nos. 2, 3) is not known. Its provenance could reveal more information about why and when this particular type appeared in the museum, and consequently, it could help to set the other spectacles in the collection in a more detailed context. However, a mere comparison of simple metal wire rims with finely elaborated sidepieces of tortoiseshell spectacles provides us with information about craftsmanship in the spectacles industry as well as about the social background of those who wore them.

\section{Spectacles in the Náprstek Museum Collection}

The collection in the Naprstek Museum contains the spectacles from the late $19^{\text {th }}$ century to the early $20^{\text {th }}$ century. They show differences in technology, aesthetic styles and materials. The earliest is the pince-nez type without sidepieces or straps to secure the spectacles around the head or around the ears, ${ }^{11}$ while later types are represented with round rims with metal sidepieces made either of tortoiseshell or artificial materials with clear or coloured lenses. The spectacles are accompanied with three types of cases. The earliest example of pince-nez is stored in a solid wooden box. The inside of the box

${ }^{11}$ Drawings of Chinese people with round spectacles with straps around one's ears are found in Bock, 1903: 4. A picture of a man with spectacles with long straps hanging from behind the ears to his chest, Davis, 1836: 274. 
is designed according to the shape of folded eyeglasses so that the lenses cannot be damaged. Later cases are also solid, made of glued paper, and covered with finely woven fabrics and embroidery with various good-luck symbols. The symbols and even a little poem embroidered on the silk textile (No. 6) shift the meaning of the every-day use objects to a personal statement.

Although the collection is rather small, due to its variety it is possible to show the social context of the objects that refer to different lifestyles of Chinese society of the late $19^{\text {th }}$ and early $20^{\text {th }}$ century. The pince-nez (No. 4) is stored in a container with glued sheets of printed paper that gave not only the name and an address of the workshop but also an advertisement with an invitation for the purchase and a guarantee of the quality and a promise to replace the purchase if the lenses did not match the desired value. This type of pince-nez could have belonged to a traditional Chinese scholar. ${ }^{12}$ Two wirerimmed spectacles show the mass production of cheap and easily accessible goods for ordinary customers. Even their cases, although embroidered, could not compare with the carefully embroidered spectacles cases. However, their meaning as a "cheap" but fashionable ornament should also be taken into account. ${ }^{13}$ Tortoiseshell and plastic spectacles with elaborate sidepieces could have been in possession of an ambitious man living in a cosmopolitan port city. ${ }^{14}$

\section{Catalogue $^{15}$}

\section{No. 1}

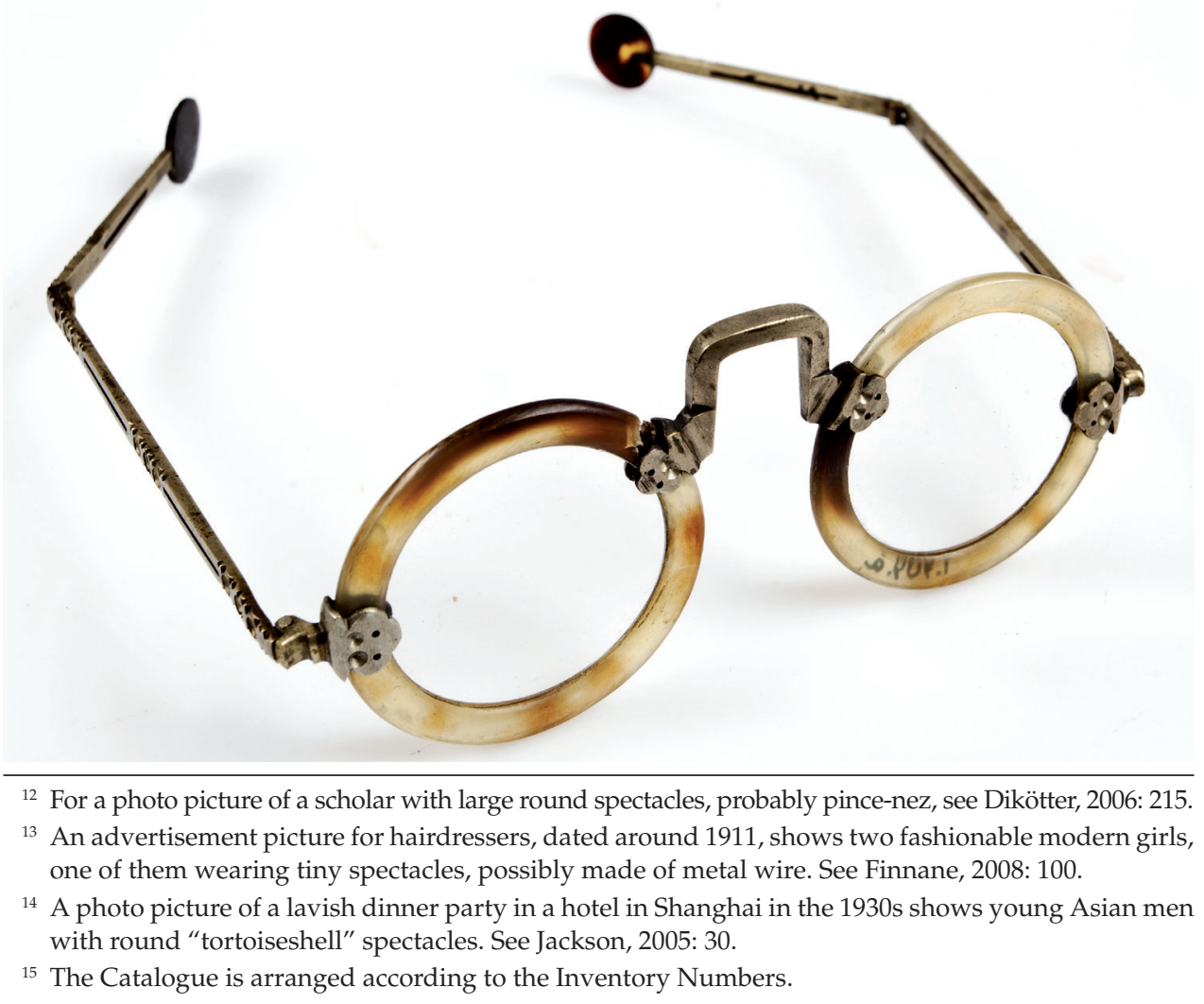


Inv. No. 1909ab

Spectacles and the spectacle case

Acquisition: Enrique Stanko Vráz, 1904

Spectacles: length $12,7 \mathrm{~cm}$, diameter $4,8 \mathrm{~cm}$

Round frames (tortoiseshell) with quadratic " $\mathrm{C}$ " bridge, metal folding arms and ring ends made of tortoise-shell (?)

The lenses are dioptric

No. 2
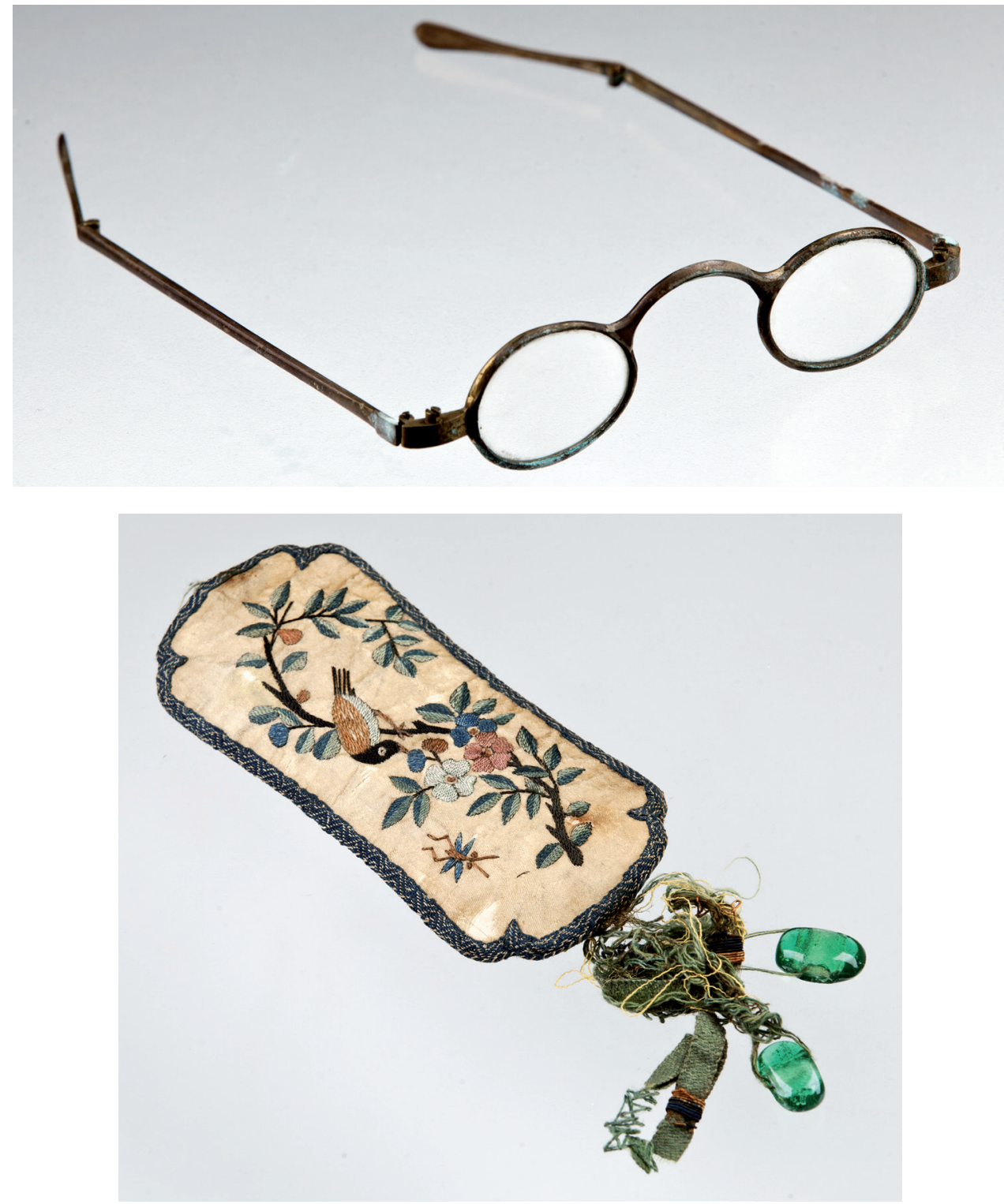
Inv. No. 20224ab

Spectacles and the spectacle case

Not dated, presumably $2^{\text {nd }}$ half of the $19^{\text {th }}$ century, early $20^{\text {th }}$ century

Spectacles: length 9,5 cm, diameter 3,4 cm

Oval metal frames with " $\mathrm{C}$ " bridge, metal folding arms

The lenses are dioptric

Case: length $12,4 \mathrm{~cm}$, width $5,1 \mathrm{~cm}$

An oval case, flat, soft, made of paper and textile. Yellow satin, embroidery: birds and insects among flowers, two sides have a different embroidered motif Textile ribbon with two green glass flat beads

No. 3
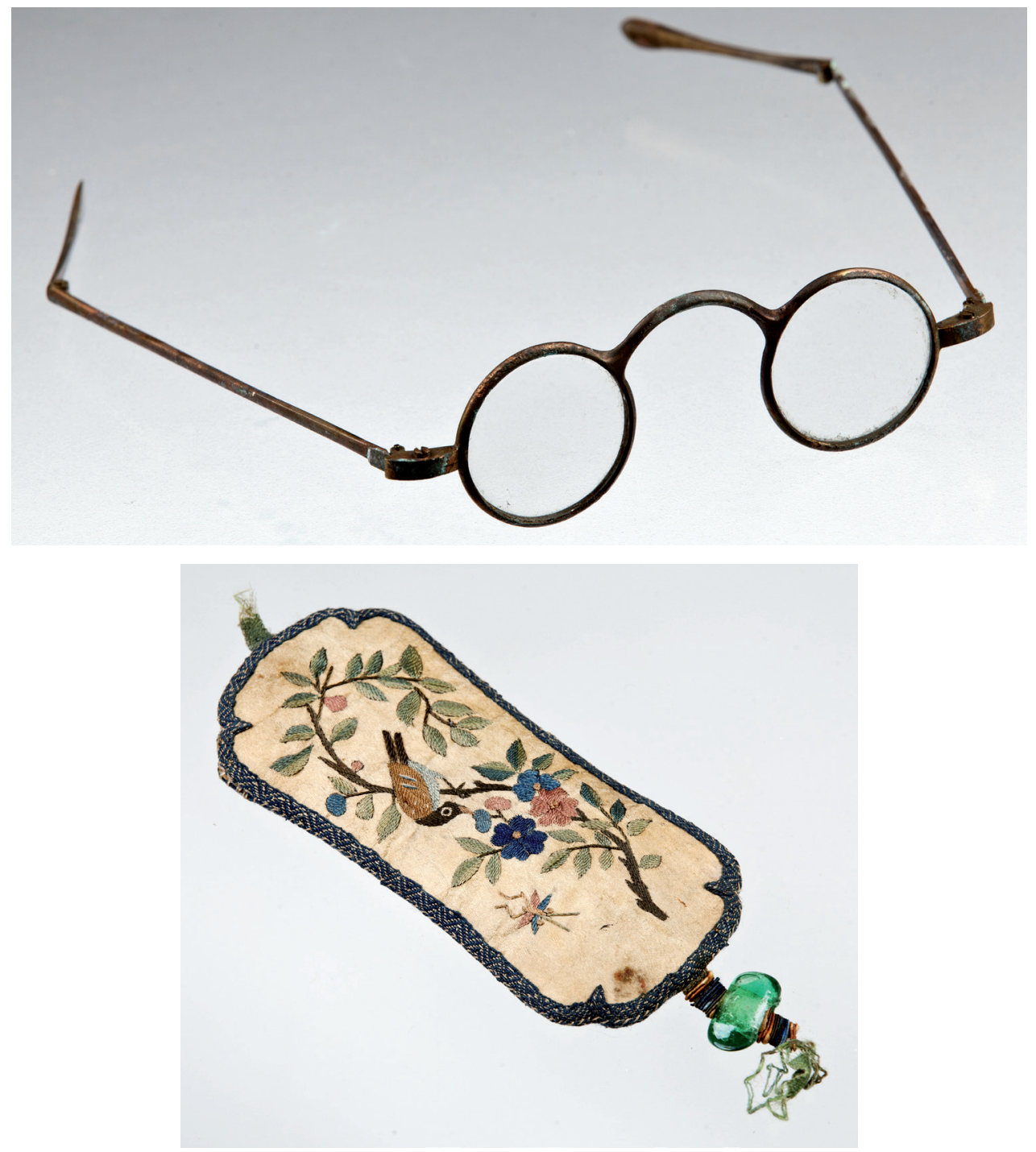
Inv. No. 20225ab

Spectacles and the spectacle case

Not dated, presumably 2 nd half of the $19^{\text {th }}$ century

Spectacles: length $8,8 \mathrm{~cm}$, diameter $3,2 \mathrm{~cm}$

Round metal frames with " $\mathrm{C}$ " bridge, metal folding arms

The lenses are dioptric

Case: length $12,3 \mathrm{~cm}$, width $5 \mathrm{~cm}$

Oval, flat, soft, made of paper and textile

Yellow satin, embroidery: birds and insects among flowers, both sides are similar

Ribbon with a green oval flat glass bead

No. 4

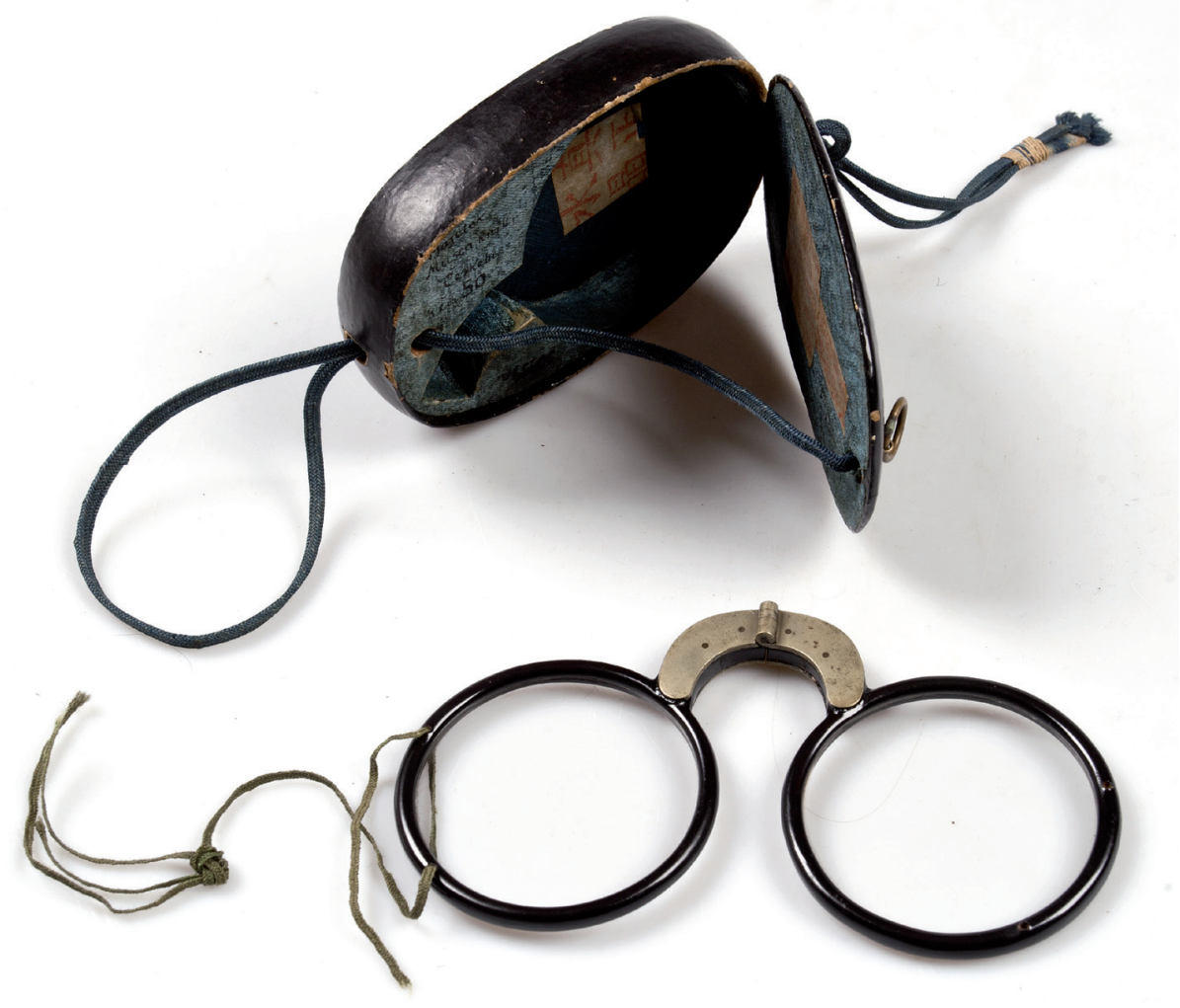

Inv. No. 30959ab

Spectacles (pince-nez) and the spectacle case

Acquisition: Museum království českého (Museum of Czech Kingdom), gift of Mr. Ivanin from Petrohrad (Russia)

Not dated, mid-19th century

Spectacles: length $14,5 \mathrm{~cm}$, diameter $6,5 \mathrm{~cm}$

Inside the case the spectacles are folded 
The lenses are thin and light and slightly damaged

Round frames made of light wood, brown colour varnish, with a heavy metal " $\mathrm{C}$ " bridge, folded in half

On the bridge, four Chinese characters are engraved which indicates a workshop:

鐘 錦豊製 (Bell, Splendid Abundance manufactured)

Black ink inscription: Museum království českého, č.50 (Museum of Czech Kingdom, No. 50)

Case: length $11,9 \mathrm{~cm}$, width $8,2 \mathrm{~cm}$, thickness $3,2 \mathrm{~cm}$

Oval, two parts secured with a textile cord. Wood, paper, textile, brown colour varnish

Inside the case the inscription is in black ink:

Majetek Musea království českého, číslo 50 (Property of the Museum of Czech Kingdom, No. 50)

Three pieces of paper with red ink printed texts in Chinese:

a) 真正水品

Genuine quartz

b) 水品眼鏡如假包换

Quartz spectacles

If forged replacement guaranteed

c）在寧波鼓楼前

坐東朝西門面

錦豊字號自造

水品墨品玻璃

各式眼鏡簇客

In Ningbo ${ }^{16}$ in front of the Drum Tower ${ }^{17}$

Facing the West Gate

The Company Splendid Abundance (Jin Li 錦豊) produces

Quartz, smoky, glass

All kinds of spectacles flourish here.

No. 5

Inv. No. 30960

\section{Spectacles and the spectacle case}

Acquisition: Václav Stejskal, 1940 (1940 Náprstek Museum Acquisition book: „zwei chinesische Brillen")

\footnotetext{
${ }^{16}$ A city in the northeast Zhejiang Province, PRC. In the second half of the $19^{\text {th }}$ century, one of the treaty ports with flourishing craftsmanship and commerce opened for foreign trade.

${ }^{17}$ The traditional commerce area in Ningbo 寧波, in modern Haishu海 曙 district.
} 

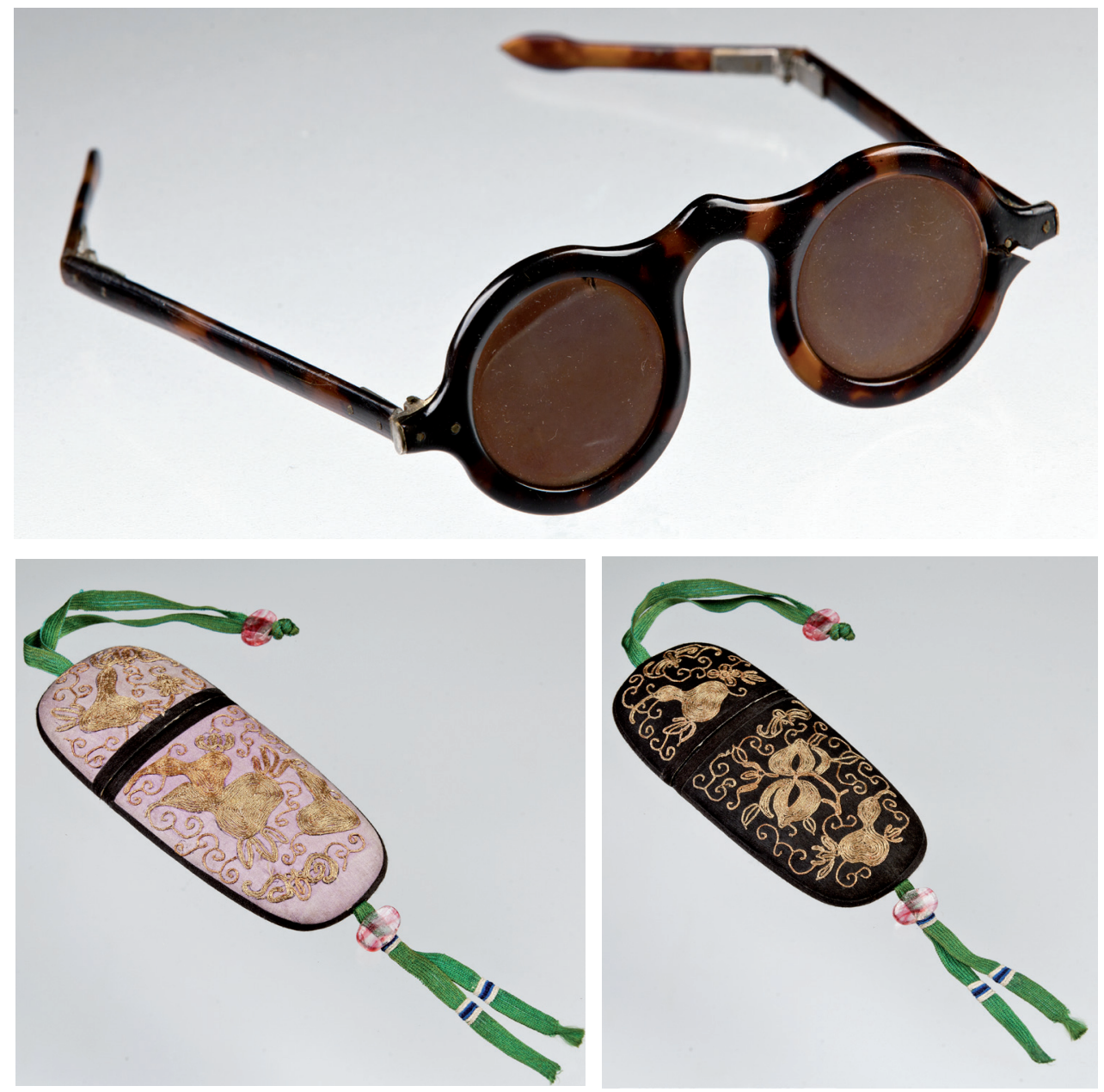

Acquired in China during Stejskal's journey on the board of the corvette Aurora to Asia in 1886/1888

Spectacles: length $12,4 \mathrm{~cm}$, diameter $4,5 \mathrm{~cm}$

Tortoiseshell frame, dark lenses

Case: length $14,8 \mathrm{~cm}$, width $6,5 \mathrm{~cm}$, thickness $2,7 \mathrm{~cm}$

Oval, two parts, paper, pink and black silk satin, with a green flat cord and two flat glass beads in pink colour. Goldwork: gourds, bats, flowers and peaches, leaves among tendrils. The design of each side differs a little

No. 6

Inv. No. $30961^{18}$

Spectacles and the spectacle case

Acquisition: Václav Stejskal, 1940 (1940 Náprstek Museum Acquisition book: „zwei chinesische Brillen")

${ }^{18}$ Published in Heroldová, 2011: 74, 112-113. 

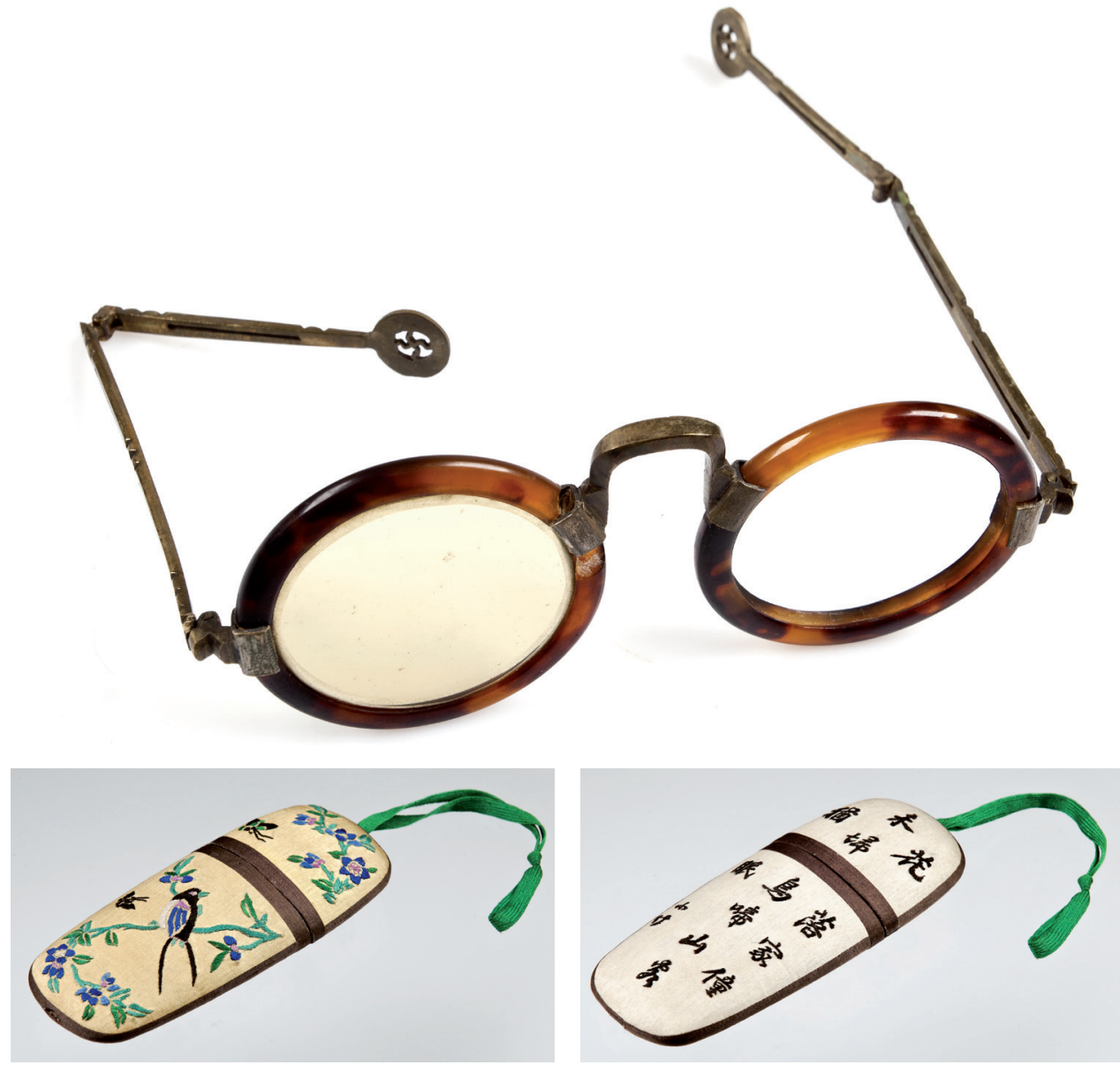

Acquired in China during Stejskal's journey on the board of the corvette Aurora to Asia in 1886/1888

Spectacles: length $13,6 \mathrm{~cm}$, diameter $5,4 \mathrm{~cm}$

Slightly yellow-coloured glasses (one missing), a tortoiseshell frame, a metal quadratic " $\mathrm{C}$ " bridge, metal folding arms with round ends with a swastika design

Case: length $15,9 \mathrm{~cm}$, width $6,6 \mathrm{~cm}$, thickness $2,7 \mathrm{~cm}$

Oval, two parts. Paper, silk satin, yellow colour, with flat green cord.

One side: embroidery, a bird, butterflies among flowers and leaves.

One side: embroidery, a poem:

\section{花落家僮未埽 \\ 鳥啼山客栖眠。 \\ 小竹}

Flowers fell down

The boy servant has not swept them away

Birds cry 
The passenger in the mountains sleeps under the oaks

(Little Bamboo)

No. 7

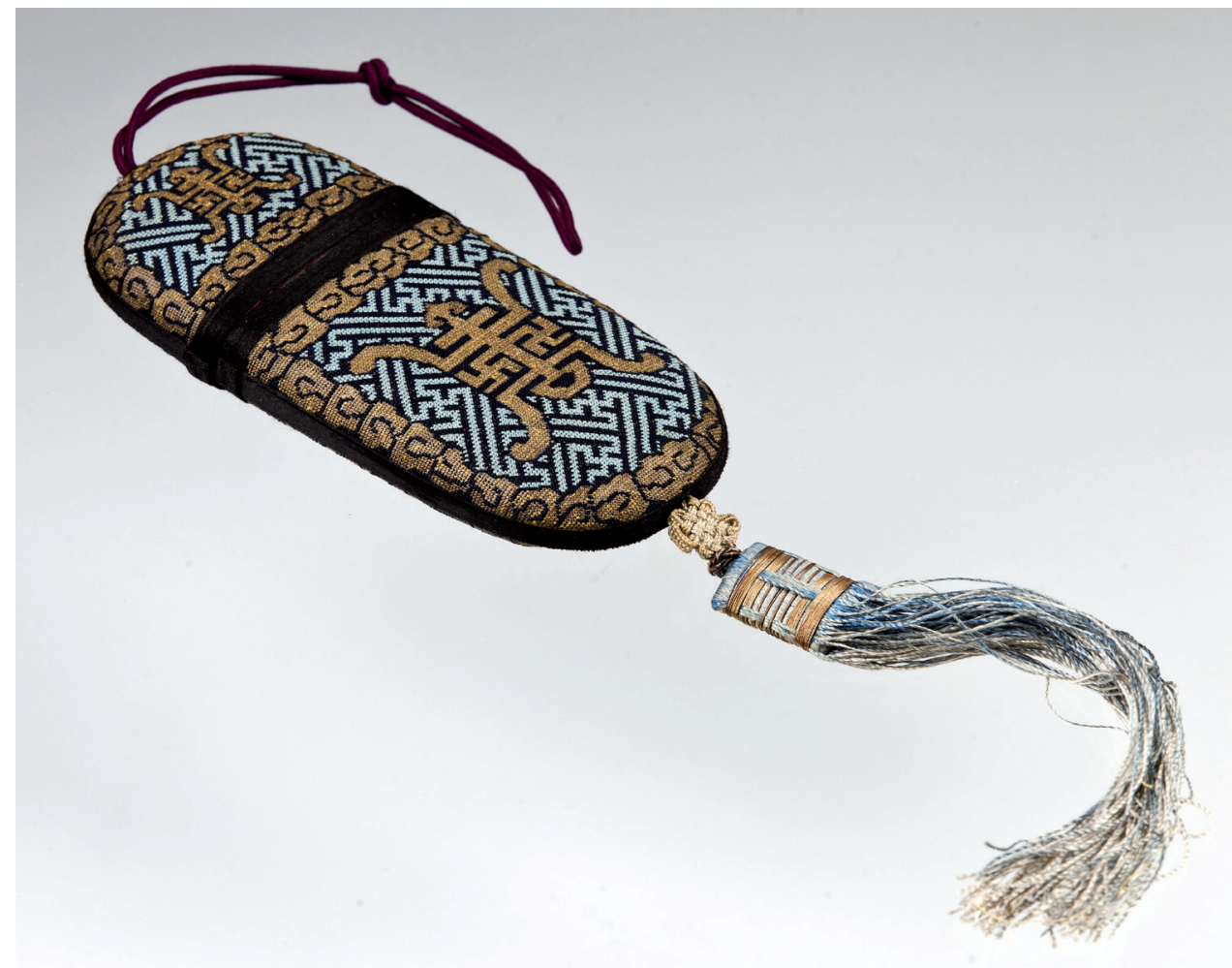

Inv. No. 33093

Spectacle case

Acquisition: Joe Hloucha

Not dated, late $19^{\text {th }}$ century, early $20^{\text {th }}$ century

Case: length $16,1 \mathrm{~cm}$, width $6,8 \mathrm{~cm}$, width $2,3 \mathrm{~cm}$

Oval, two parts, paper, brown cord and a blue tassel with the "endless" knot made of paper. On both sides the same embroidery, golden thread on gauze (diagonal tent stitch, Paine, 240: 231): two characters shou 壽 ("Longevity"), two swastikas wan ఔ on the background made of wan characters and clouds, blue and golden colours. The characters shou and wan together create the meaning "Long Life" (Welch, 2008: 215, 261) 
No. 8
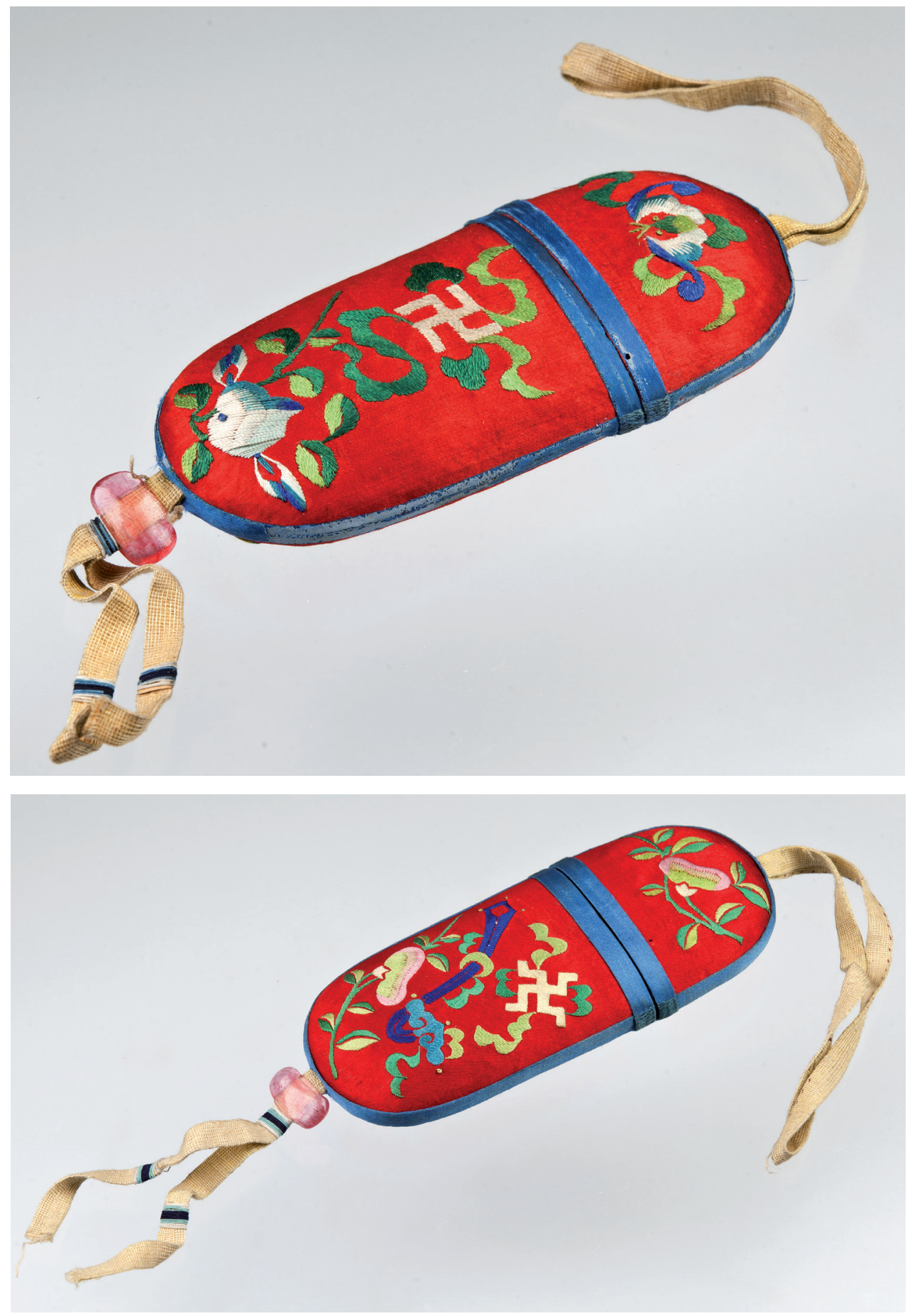
Inv. No. 33095

\section{Spectacle case}

Acquisition: Joe Hloucha

Not dated, late $19^{\text {th }}$ century, early $20^{\text {th }}$ century

Case: length $15,5 \mathrm{~cm}$, width $6,8 \mathrm{~cm}$, width $2,5 \mathrm{~cm}$

Oval, two parts, red silk satin, with yellow flat cord and a flat oval glass bead in pink colour. On both sides are the same embroidery: ruyi 如意 (“According to Your Wishes") sceptre, the swastika wan ఔ, stylised flower with leaves in yellow, green, blue and pink colours. Sceptres (ruyi) represent real objects with symbolic meaning. They mean wishes for longevity, and they were given during important occasions such as birthdays of elderly members of the family. Motifs of ruyi sceptres on textile, porcelain, paintings, etc. also represent auspicious meanings (Welch, 2008: 258-259).

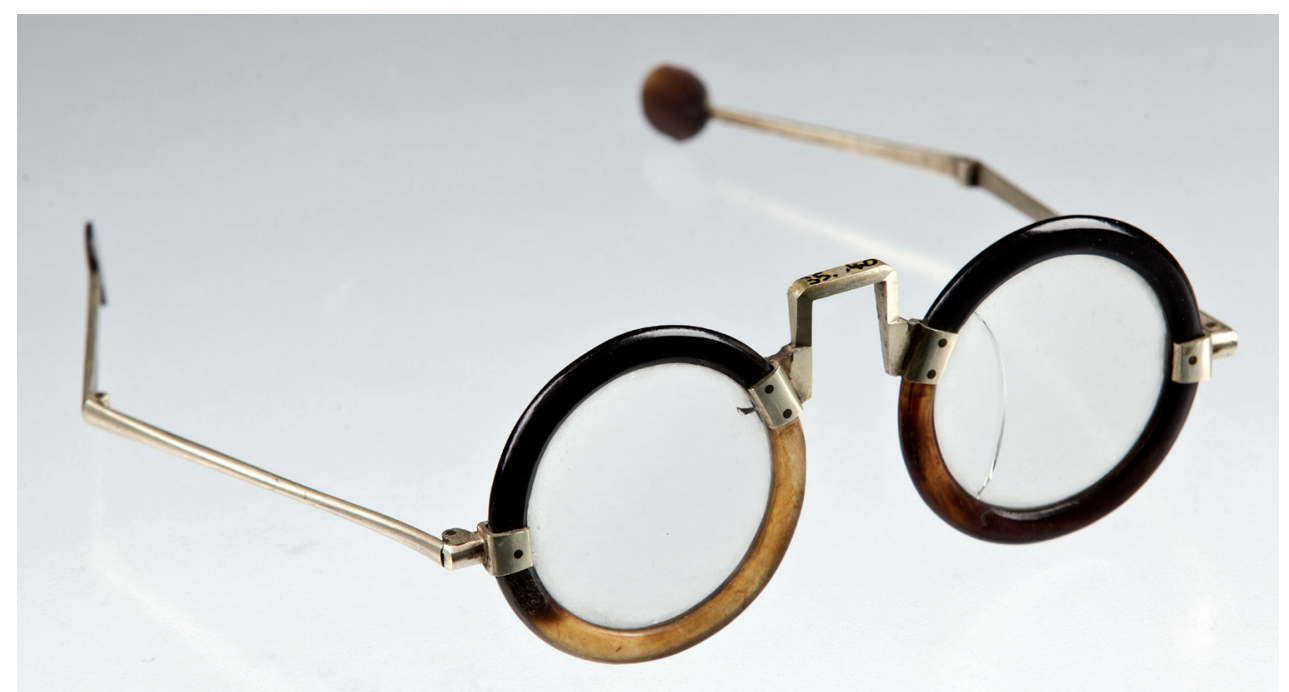

No. 9

Inv. No. 35040

Spectacles

Acquisition: Joe Hloucha

Not dated, late $19^{\text {th }}$ century, early $20^{\text {th }}$ century

Spectacles: length $11,3 \mathrm{~cm}$, diameter $4,7 \mathrm{~cm}$

Round frames - tortoiseshell (?), a metal quadratic " $\mathrm{C}$ " bridge,_metal folding arms with round ends made of tortoiseshell (?) 
No. 10

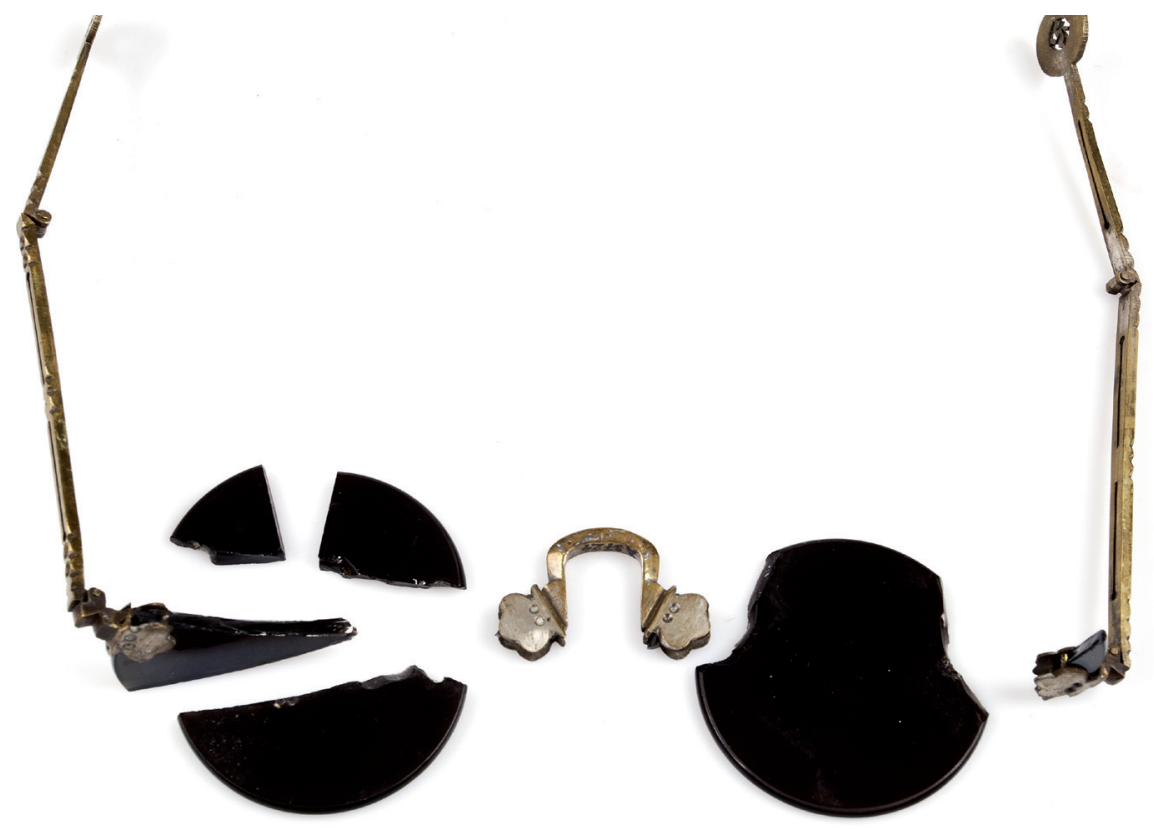

Inv. No. A/3724

Spectacles

Acquisition: Prof. Kračmera

Not dated, late $19^{\text {th }}$ century, early $20^{\text {th }}$ century

Length $12,7 \mathrm{~cm}$

A fragment of spectacles with dark glasses, a metal frame, metal quadratic " $\mathrm{C}$ " and folding arms with round ends with a swastika design. 


\section{Literature:}

\section{Agarwal, Rishi Kumar}

1971 "Origin of spectacles in India." British Journal of Ophthalmology, Vol. 55, No. 2, pp. 128-129.

\section{Bertolucci, Bernardo, director}

1987 The Last Emperor. Hemdale Film Corporation.

\section{Bock, Emil}

1903 Die Brille and ihre Geschichte. Wien: Josef Šafár.

\section{Chen, Kaijun}

2018 "Transcultural Lenses: Wrapping the Foreignness for Sale in the History of Lenses." In Grasskamp, Anna and Monica Juneja, eds. China, Europe, and the Transcultural Object, 1600-1800. Springer, pp. 77-98.

\section{Chiu, Kaiming}

1936 "The Introduction of Spectacles Into China." Harvard Journal of Asiatic Studies, Vol. 1, No. 2, pp. 186-193.

\section{Davis, John Francis}

1836 The Chinese: A General Description of the Empire of China and Its Inhabitants. C. Knight.

\section{Dikkötter, Frank}

2006 Exotic Commodities: Modern Objects and Everyday Life in China. Columbia University Press.

\section{Finnane, Antonia}

2008 Changing Clothes in China. Fashion, History, Nation. Columbia University Press.

\section{Garret, Valery}

2001 M. A Collector's Guide to Chinese Dress Accessories. Times Editions.

\section{Finlay, Robert}

2000 "China, the West, and World History in Joseph Needham's Science and Civilisation in China." Journal of World History, No. 11, pp. 265-303.

\section{Heroldová, Helena}

2017 Between Cultures: Manchu and Han Dress during the Late Qing. Praha: Národní muzeum.

2011 The Exotic Salon of the Master of the House: The History of the Václav Stejskal Collection. Praha: Národní Muzeum.

\section{Heroldová, Helena - Jiřina Todorovová}

2018 "A Family Portrait: E. S. Vraz and the Qing Aristocracy during the Boxer Rebellion." Annals of the Náprstek Museum, Vol. 39, No. 1, pp. 51-74.

Jackson, Beverley

2005 Shanghai Girl Gets All Dressed Up. Berkeley: Ten Speed Press,.

Kraemerová, Alice - Jan Šejbl

2007 Japonsko, má láska: český cestovatel a sběratel Joe Hloucha. Praha: Národní muzeum.

\section{Lackner, Michael - Natascha Vittinghoff (eds.)}

2004 Mapping Meaning: The Field of New Learning in Late Qing China. Brill. 


\section{Laufer, Berthold}

1907 "Zur Geschichte der Brille." Mitteilungen zur Geschichte der Medizin und der Naturwissenschaften, Vol. 6, No. 4, pp. 379-385.

Mazor, Amir - Keren Abbou Hershkovits

2013 "Spectacles in the Muslim World: New Evidence from the Mid-Fourteenth Century." Early Science and Medicine, Vol. 18, No. 3, pp. 291-305.

\section{Needham, Joseph}

1962 Science and Civilisation in China. Vol. IV. Physics and physical Technology. Cambridge: Cambridge University Press, 2004.

Aisin-Gioro, Puyi

1965 From Emperor to Citizen: Autobiography of Aisin-Gioro Pu Yi, Volume 1. Beijing: Foreign Language Press.

\section{Rasmussen, Otto Durham}

1915 Old Chinese Spectacles. Tientsin: North China Press.

\section{Rosenthal, William, J}

1996 Spectacles and Other Vision Aids: A History and Guide to Collecting. San Francisco: Norman Publishing.

\section{Welch, Patricia Bjaaland}

2008 Chinese Art. A Guide to Motifs and Visual Imagery. Tuttle Publishing.

Wright, David

2000 Translating Science: The Transmission of Western Chemistry into Late Imperial China, 1840-1900. Brill. 